
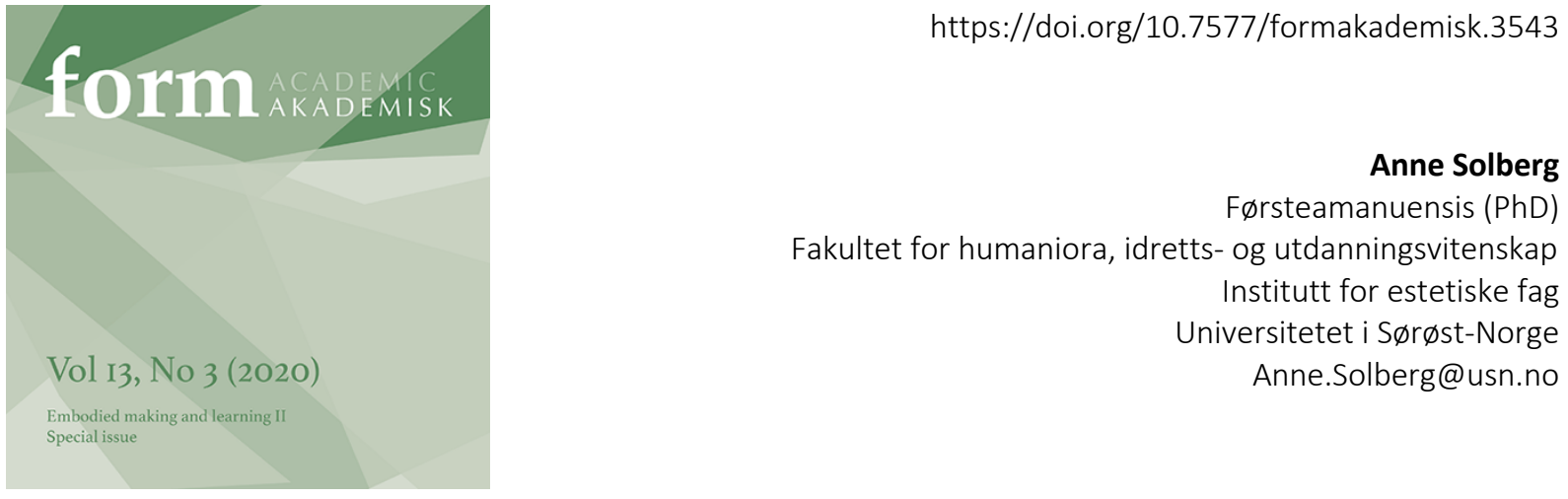

\title{
Enigmatic epistemic things
}

\section{The epistemic role of artworks in artistic research doctorates}

\begin{abstract}
The aim of this article is to contribute to the present discussion of artistic research epistemology, regarding doctoral works as well as the wider scope of research projects Hans-Jörg Rheinberger's theory on experimental systems and epistemic things is at the core of this epistemological discussion. Rheinberger advocates for an objective and practice-oriented approach rather than a theoretical approach to experimental research. In his setting, epistemic things are material. In this article, an artistic research enterprise, the Porcelaneous Project, serves as an example from the practice field. The article concludes that the theory on experimental systems and epistemic things is relevant even to small-scale artistic research experiments. The term 'epistemic things' is found to be a useful element to the enigmatic character of artistic expression.
\end{abstract}

Keywords:

epistemic things, experimental systems, artistic research, doctoral research, hand-built porcelain

\section{INTRODUCTION}

In the emerging field of artistic research, discussions on research methods and epistemology are frequent and ongoing. The focus of this article is on the epistemic status of artworks and art-making in research projects. Artworks can play various roles in this process; they can be the object of investigation, the working tools of research or the results of the project. The latter is a current issue of debate in academic settings, concerning artistic research as such, and in PhD programmes in particular. At present, many countries have two different lines of doctorates: scientific doctoral programmes and artistic doctoral programmes. In some cases, artistic doctoral programmes lead to the awarding of a Dr Art, which is not a PhD degree. In Norway, a similar programme leads to a PhD in artistic research, with the suffix of artistic research as a mandatory connotation, in order to designate that this is not an ordinary PhD. The role of artworks is one of the main reasons for these distinctions between scientific 
and artistic doctorates. Some institutions accept artworks as a research result, while others do not. However, the connotation, PhD, does not follow this distinction throughout. Hence, the ambitions of the Bologna Process of clarifying the criteria of the third cycle, the doctoral level, does not fully apply to the field of artistic research (Solberg, 2017).

This article is the first in a series on various approaches to artistic research. The Porcelaneous Project, a three-year artistic research project about making porcelain boards, provides examples for the discussions in the series of articles. In this first article, I discuss experiments as an approach to epistemic questions within artistic research, well aware that this is merely one of a number of approaches that are being developed and discussed.

In general, experimental research is characterised by some kind of action or manipulation of a situation. This is the case in several disciplines, in the natural as well as the social sciences. In this article, I use Hans-Jörg Rheinberger's theory on experimental systems and epistemic things as a frame of reference. Rheinberger is a biologist and a science historian, and the former leader of the Max Planck Institute of Science History. He introduced this theory in his studies of science history (Rheinberger, 1997a, 1997b). In his writings within science history, Rheinberger elaborates on his reflections on the importance of concrete laboratory work in scientific research. He advocates for material experiments rather than theoretical constructions to facilitate innovation and generate knowledge. I chose this approach to investigate whether this perspective on epistemology, which was developed in the field of biology, can be fruitful for the field of artistic research, and whether this approach may be relevant to the discussion of the role of artworks in doctoral research.

For this article, sources of information on Rheinberger's theory include several of his academic publications as well as comments on these from other scholars, mainly from the fields of art. Most of these comments are found in Experimental Systems Future Knowledge in Artistic Research, edited by Michael Schwab (Schwab, 2013a), which also includes an interview with Rheinberger. In this article, I use my porcelain project (Porcelaneous) to provide examples from the practice field. As in artistic research in general, art practice and investigation are intertwined in this project in the perspective of the theory of artistic research, which, in turn, is concretised by the porcelain items. The development of the artworks entails the iterative interaction between the making of full-scale boards in porcelain and sketches on paper during the creation process. All the items are documented and dated. Some of them are rendered in this article. The artworks reflect the fact that the porcelain project was in its initial phase at the time this article was written. Hence, most of the examples are initial efforts towards developing a proper craft technique. Some of the artworks also represent the first series of fullscale boards and starting points of new of lines of inquiry of the porcelain project. These will be elaborated upon in future articles as examples related to various research approaches.

\section{EPISTEMOLOGY \\ Artistic research}

In this article, artistic research is used as a common denominator for practice-based research within the arts, including music, visual arts, the performing arts and affiliated areas. Artistic research differs from art making, as such, due to its investigative approach and the academic demands of the research project. Artistic researchers must undertake three major actions. First, they must develop their own artistic craft and conceptualise it. Second, they must contribute to academia by proposing an argument in the form of a thesis, which should contribute to the emerging field of artistic research. Third, artistic researchers must communicate with practicing artists and the public (Hannula et al., 2014, p. xi).

Artistic research also differs from approaches where artistic means are used as research vehicles; in this case, the object of research is a broad scope of issues, within the social sciences in particular, rather than the artwork. In my understanding of the term, artistic research applies to projects where artworks are both the object of research and the research output. According to Borgdorff (2011): 
(...) we can justifiably speak of artistic research (research in the arts) when that artistic practice is not only the result of the research, but also its methodological vehicle, when the research unfolds in and through the acts of creating and performing. (p. 46)

Authors have described this dynamic as a process of continuously shifting back and forth between an inside and outside perspective (Biggs \& Büchler, 2011; Borgdorff, 2011; Hannula et al., 2014; Lucas, 2013). Hannula et al. (2014) characterised it as a minor distance and a relative outsider's perspective. This includes a meta-perspective on context.

Research is then done inside-in, while reaching out and getting out of one's box in order to return to it again, not superimposed from outside but developed and taken care of from within. It is a collection of acts that are called not a progress but a never-ending, self-reflective and critical, creative process. (Hannula et al., 2014, p. 14)

Borgdorff (2011) described a distinctive change of mind between the two perspectives. 'Artistic research-embedded in artistic and academic contexts-is the articulation of the unreflective, nonconceptual content enclosed in aesthetic experiences, enacted in creative practices and embodied in artistic products' (p. 47). In my view, the characteristic, 'un-reflective and non-conceptual', is disputable, but this discussion is beyond the scope of this article. This twin perspective, from the inside and outside by the same person, the practicing-researcher or the artist-researcher, has been the object of lively debate in artistic research. The debate has raised fundamental questions about the legitimacy and validity of this kind of research.

\section{Experiments and epistemic things}

The term, experiment, has had different meanings in the field of art over time. In the 1950s and 1960s, experimental art represented a break with tradition, and it was closely linked to the avant-garde movement of the $20^{\text {th }}$ century. This has become an epoch in art history and a tradition in itself (Stallschus, 2013). In the 1960s, experimental art gave way to conceptual art. Schwab (2015) argued that divergence from the notion of experimentation was needed to distance art from the scientific paradigms of the early $20^{\text {th }}$ century. He recommended a post-conceptual return to experimentation as an epistemic process, arguing that this would do justice to the material practices that have remained important to so many artists, also in the era of conceptualism (Schwab, 2015, n.p.).

Given that the concept of experimental art is linked to a particular era of art history, artistic experiments, as such, still tend to have an explorative character. Dyrssen (2011) described it this way:

Explorative experiments should subvert conventional strategies; shake up ingrained patterns of thought; provide quick feedback, increased curiosity, and discoveries of hidden possibilities; reveal possible links and points that need to be mapped; and get the creative process moving forward. The driving forces in the explorative process are invention and discovery (p. 229).

However, she warns that these kinds of open-ended, explorative experiments run the risk of having starting points that are too vague; they may also investigate issues that are already known (Dyrssen, 2011, p. 229).

Laboratory experiments are an accepted research method in the natural sciences. This section presents a brief introduction to Rheinberger's theories of experiments as the core generator of scientific knowledge. In his seminal historiographic study of research on protein synthesis, Rheinberger (1997a) suggested that experimental systems are the motor of modern scientific research. In his terminology, experimental systems are the smallest integral working units of the experimental sciences. They include different aspects of the scientific research process, such as skills, instruments, preparations, research objects and the spaces where these interact. Hence in this terminology, experimental systems are not a network of experiments, but the constellation of the necessary elements in each experimental entity. Thus, science resides in these experimental entities. Science is constituted by a multitude of materiallymediated processes, rather than a collection of theoretical concepts. Practice provides the means 
needed to gain scientific knowledge (Rheinberger, 1997b, p. 247). Experiments are not only a method for testing hypotheses; they also generate new knowledge. For this purpose, experiments should be open ended. New insight is not produced by an action directed towards a goal, but by the possibilities that ensue from previous experimental processes. Consequently, the research process is repetitive and meticulous, with new experiments following previous experiments. Innovations are not pre-decided goals of these experiments; rather, they occur when open-ended experiments are conducted. Thus, innovations tend to be by-products of this process (Rheinberger, 1997a, pp. 27-28). This is what Rheinberger (1997b, p. 251) would call a context of discovery, as opposed to the hypothesis-testing experiments, which, in this perspective, represents a context of justification.

One problem of experimental research in the natural sciences is that experiments must deal with very complex objects of investigation. To make experiments possible, this complexity is frequently reduced to simplified, manageable units. Rheinberger does not recommend this kind of reductionist strategy. Rather, he considers science as an ensemble of small, locally manageable experimental systems. These entities operate in an area between the complex and the trivial, which makes them effective for reducing complexity. However, to avoid sheer triviality, these minor entities must be connected to each other within a complex epistemic horizon. There is a vast number of such small experimental entities, and the variations between them creates an experimental complexity that can lead to extraordinary constellations and unforeseen directions. In these constellations, innovations arise from unexpected events, which are not sought after. While they occur as a surprise, that does not mean that they randomly happen. They are made to happen through the dynamics of the experimental machinery. This process may also cause hybrids between independent entities and bifurcations that lead to offspring systems (Rheinberger, 1997b, p. 249).

Rheinberger divides the various components in these kinds of experiments into two categories, which he calls technical objects and epistemic things. Technical objects are the material conditions for experiments, the laboratory, the equipment, and also the qualifications of the laboratory staff. Epistemic things are what we are searching for in the experiments.

They are epistemic by virtue of their preliminarity, of what we do not yet know about them, not by virtue of what we already know about them. They are epistemic because it has not yet been determined whether they will become obsolete as targets of research, or whether they will become transformed into stable, technical objects that may define the boundary conditions of further epistemic objects. This latter category of objects is, in contrast to the former, transparent, confined, and not transcendent. And as a rule, we can point at them. (Rheinberger, 2005, p. 407)

As stated in this quote, the borders between epistemic things and technical objects are dynamic. What at one stage is an epistemic thing may turn into a technical object when the epistemic thing is clarified. Then, the laboratory can deal with new epistemic things.

The notion, epistemic things, suggests a combination of knowledge and material things. Epistemic is related to knowledge, while things is a concrete and modest notion of 'objects,' as they used to be called in academic settings. In brief, epistemic things represent what we do not yet know in a research project.

Rheinberger (2005) stated that epistemic things are material objects:

The general thrust of my whole argument is about the power of material objects-in contrast to ideas or concepts - as driving forces in the process of knowledge acquisition. (...) My goal was to provide an objectcentred, materially founded account of knowledge production. According to my position, scientific or epistemic objects are clearly material things. They function as scientific or epistemic objects by virtue of their opacity, their surplus, their material transcendence, if you like, which is what arouses interest in them and keeps them alive as targets of research. [emphasis added] (p. 406)

The fundamental principle is an object-focused approach to science rather than a theoretical approach. In my view, this constitutes practice-driven knowledge production. Hence, practice should not only be regarded as a set of repetitive, rule-driven actions, but also as dynamic, creative, constructive and 
normative actions. Borgdorff (2011) also described this as the the practice turn of science (Knorr Cetina, 2001; Rouse, 2001).

The expertise and experience of practice, sedimented into tacit knowledge, constitute a basis for creative and constructive processes that have the potential to facilitate the emergence of the unforeseen. As I see it, such practice is the core of artistic research in the same way that the practice approach of experimental systems is the core of scientific research. In this context, embodied, situated and enacted forms of cognition become more important to our understanding than world-mind representations (Borgdorff, 2013, p. 116). Tacit knowledge is partly embodied in the technical objects of experimental systems. In Rheinberger's words, the non-focal awareness of tacit knowledge allows thinking to blend with things, and vice versa; this hybrid form keeps the research moving. Borgdorff (2013) argued that epistemic things are exactly these kinds of hybrid forms in which things and thinking are interwoven. In artistic research, artworks are these kinds of epistemic things, with thinking interwoven, even if it is not yet understood. This reflects his view that art-making is pre-reflective, nonconceptual, and a product of not-yet-knowing (Borgdorff, 2013, pp. 115-117).

As a science historian, Rheinberger endorsed the art historian George Kubler's (1962) work on the history of things. Kubler (1962) regarded things to be integrations of the material and mental aspects of art in the term form. 'Science and art both deal with need satisfied by the mind and the hands in the manufacture of things' (Kubler, 1962, p. 9). Kubler suggested that every artwork is a hard-won solution to an artistic problem. These artistic solutions can be grouped into what he called sequences, which is a concept borrowed from mathematics. He structured art history into sequences, rather than historical epochs. Sequences are structured units of artistic development, interconnected in non-linear networks of artistic influences. Similar network structures are present in Rheinberger's model of small, interconnected research systems.

Rheinberger suggested that epistemic things are to science what a statue is to the art of sculpture or a picture is to the art of painting. In his terminology, these are the scientific real. They are facts, something that has been made, not data that was given beforehand. Scientific and artistic research both deal with something real, while simultaneously transforming it into what it might be. As epistemic things, artworks are not just generators of knowledge. They are also that which is generated (Borgdorff, 2013, pp. 218-219). As I understand this, in research projects artworks are not just research methods, they are also the result of research.

The incompleteness or 'non-identity' of artworks as epistemic things, that is, of art as research, makes room for the un-thought about and unexpected (Borgdorff, 2013, pp. 218-219). I regard this incompleteness as being an enigmatic character of artworks as epistemic things, a search for the hardto-grasp artistic expression that cannot be fully explained verbally in an academic setting. This incompleteness will also be present in PhD projects within the field of artistic research, where room for the un-thought an unexpected might dispute the idea of a linear progress from a distinct research question to a conclusive research output.

\section{PORCELAIN BOARDS}

The Porcelaneous Project resides within the field of material-based art. The Norwegian origin of this field of art is kunsthåndverk, a movement from the 1970s in which mainly utilitarian artefacts were made in an artist's studio, avoiding factory-based mass production. It differed from the previous brukskunst (arts and crafts) movement, which included factory production. Over time, kunsthåndverk has moved away from its origin of applied art, crossing the border to fine art, while still demanding good artisanship. Practitioners categorise their work according to the use of materials, such as wood, metal, textiles and ceramics. In some cases, this is also reversed. The Norwegian artist, Jan Groth, started as a painter but later turned into tapestry, arguing that his unsuccessful paintings succeeded when they were woven (Groth, 2015). The following section discusses a series of efforts to make porcelain boards within the tradition of material-based art. The focus of the efforts is the artistic expression of the material and the boards; simultaneously, the craft of making them is a prerequisite for obtaining these artistic objectives. 


\section{Sketching}

The Porcelaneous Project items are hand-built boards in black porcelain clay with white clay intarsia, painted with transparent layers of liquid white porcelain slip. The initial tests were $30 \times 30 \mathrm{~cm}$ tiles, shrinking to $25 \times 25 \mathrm{~cm}$ when fired. The full-scale porcelain boards are $40 \times 40 \mathrm{~cm}$ during the making process and $35 \times 35 \mathrm{~cm}$ when fired. Figure 1 depicts the process of crossing the border from applied art to fine art, striving to meet the demands of good craftsmanship.
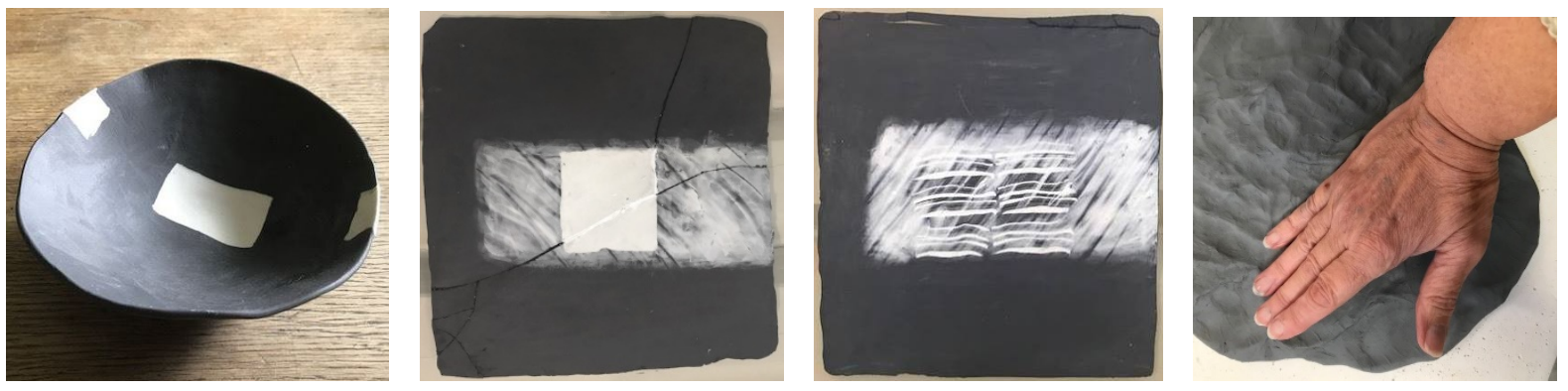

FIGURE 1. The first material sketches. Bowl: June 2018. Tiles: December 2019

Hand-building gives the clay boards a particular expression. There are traces of the hand on the surface and variations in board thickness, and the edges are left raw and, to a certain degree, irregular. The inserted white and striped intarsia shapes necessarily have these hand-built irregularities because the clay is soft during the making process. The translucent white porcelain slip, painted with a brush and smoothed with a rubber tool, has traces of handwork.
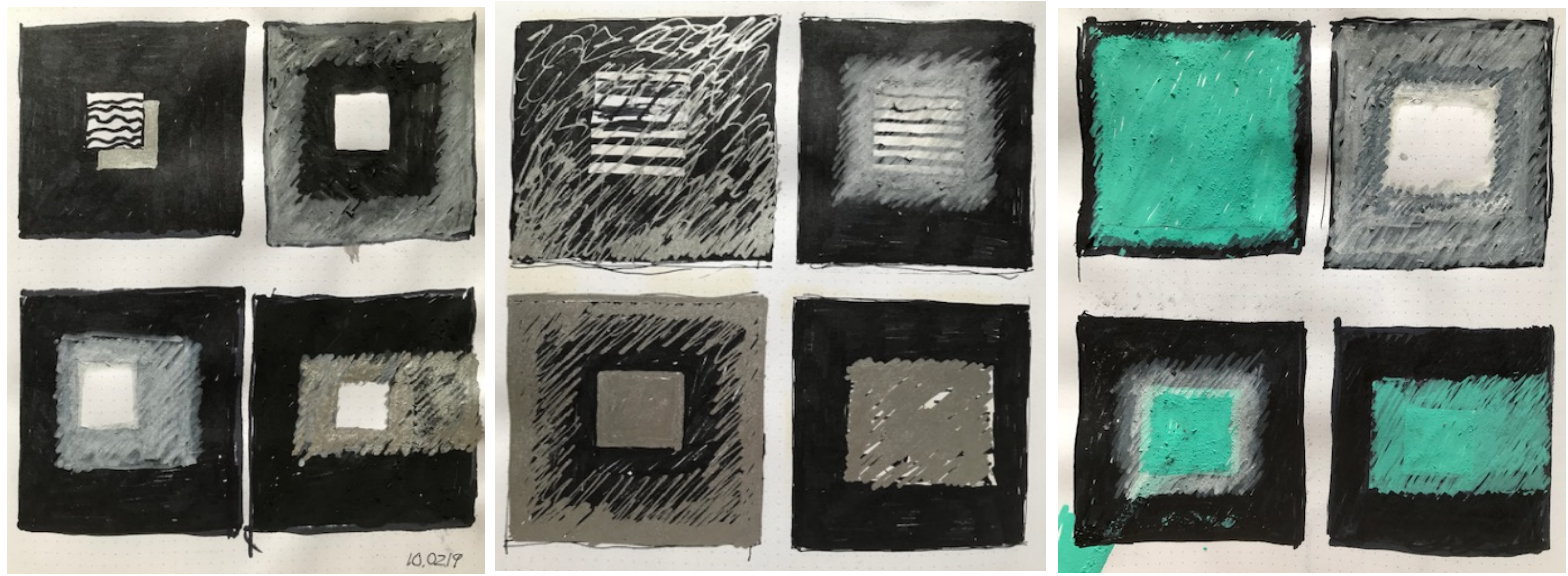

FIGURE 2. Sketches on paper. From a sketchbook. White squares covered with white and turquoise semi-transparent shapes. November 2018, February 2019

Material experiments take time because they involve making, drying and firing. Throughout the entire project, ideas were drawn in parallel with material experiments in an iterative process. Drawing sketches on paper is a quick method for generating and assessing ideas, with no practical or economic consequences (Figure 2). The scope of opportunities for experimenting is by far much wider when sketching on paper before making the material. Small sketches in hardcover sketchbooks, with a date and a few notes included, proved to be a valuable source of ideas and starting points of new series of material experiments. As seen in Figure 2, the sketches represent some accurate ideas on what to make in the full-scale porcelain board series. Numerous sketches were drawn before and during the making of the boards. The sketches on paper are representations of what is going to be materialised. They are 
experiments of imagination, projective or utopic. Of note is that all the sketches were drawn with porcelain boards in mind. The possibilities and limits of the materials, techniques and sizes are the premises for the paper sketches. The material and expressive characteristics were present when drawing. As the experiments with the full-scale boards evolved, and the craft technique was improved, the sketches gradually became more realistic. Thus, the processes of sketching and making the full-scale porcelain boards were iterative, reciprocal and intertwined throughout the project.

\section{Problem solving}

Increasing the size of the boards from $30 \times 30 \mathrm{~cm}$ to $40 \times 40 \mathrm{~cm}$ proved to be troublesome. A number of items cracked during the drying process. The cracks disturbed the geometric and rather strict design of the boards and did not highlight he character of the meticulous handwork. They were obviously not intended or controlled, and in no way did they contribute to the artistic expression. From the start, the porcelain project turned into an unintended series of experiments involving technical problem solving rather than developing the artistic expression.
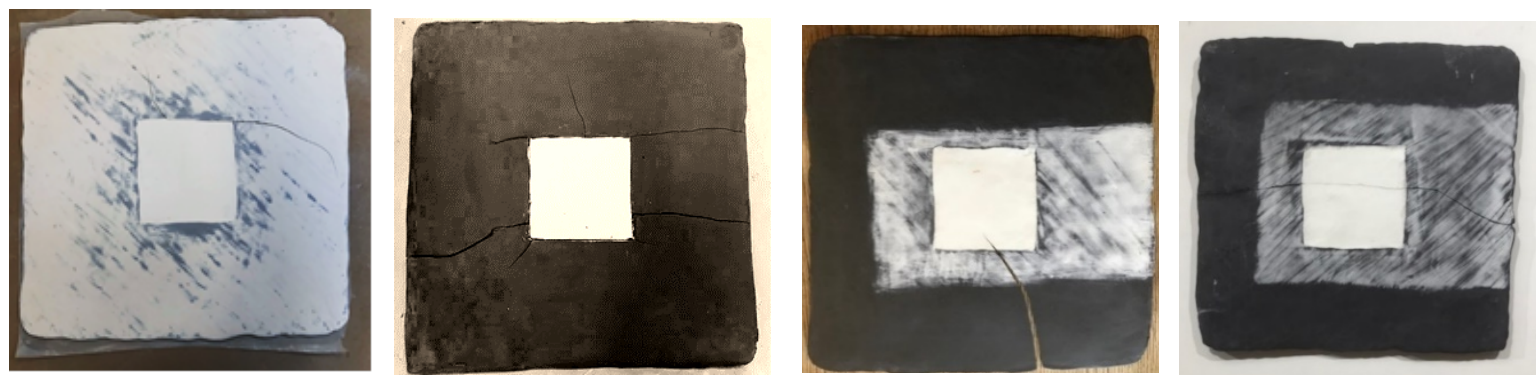

FIGURE 3. Fractures. February and March 2019

Most of the fractures were initiated from the edges of the boards, propagating inwards, sometimes across the entire board. Some cracks also started in the border between the black clay of the board and the white clay of the intarsia (Figure 3). The main reason for fracturing is the increased inner tensions in the clay as the size of the boards expand. There tends to be more tension in flat objects than in other types of shapes, and in square objects in particular (ECWC, 2005).
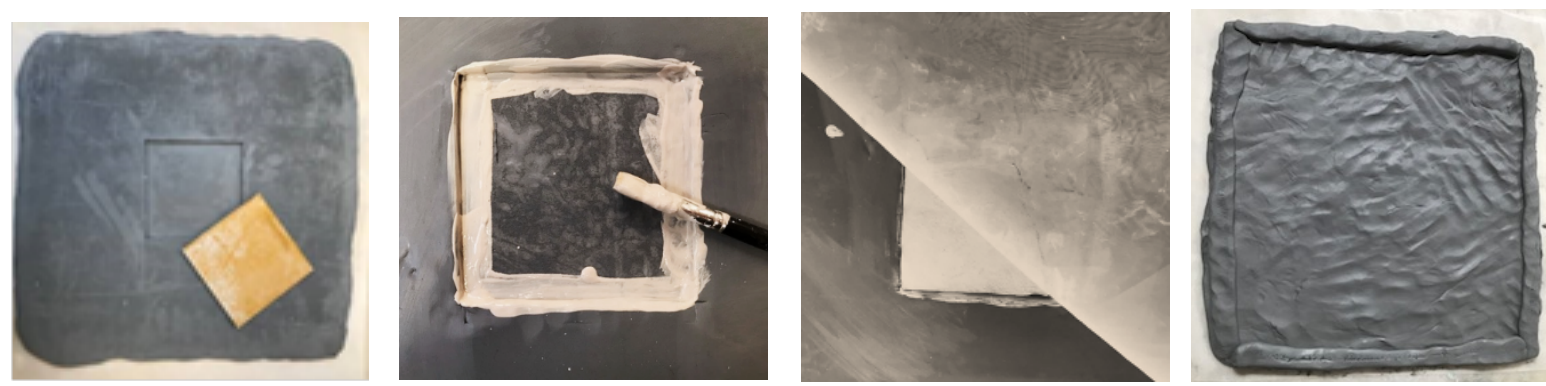

FIGURE 4. Remedies for avoiding fracturing. February and March 2019

The first series of experiments demonstrated that cracks occurred during drying for numerous reasons that required various remedies. The board could not move during shrinking because it was stuck to the underlay; using a sturdy microfiber fabric solved that problem. The fractures initiated at the borders between the white and black clays. More slip was needed to glue the two together (Figure 4). Fractures tended to occur during the last phase of drying. This phase of the process is known to be the most critical in relation to the fracturing problem (Callister \& Rethwisch, 2015). A number of fractures occurred from the edges. Covering the edges with plastic sheets mitigated that problem. Small scars on 
the edges had to be smoothed out. I also followed the advice I found in a ceramic handbook and a rim of clay was added to the edges when making and beating it into the clay body in order to strengthen the edges from the outside (ECWC, 2005). A small impurity caused by a drop of glaze on a kiln shelf resulted in a minor crack on the edge, propagating across the board when firing. After this event, I reserved a set of kiln shelves to only be used for this project.
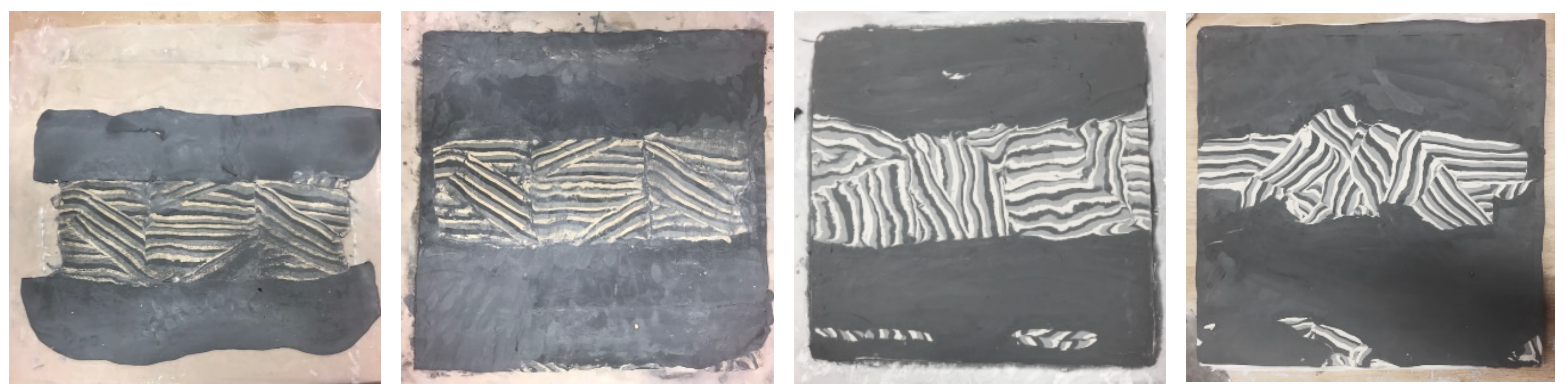

FIGURE 5. New technique: building the boards from the centre outwards. February 2020

To avoid cracking, I had to leave a stripe of the black board outside the inserted shapes of white or multicoloured clay (Figure 5). However, I wanted to stretch the inserted pieces right out to the edges. A new technique proved to allow this: building the board from the centre outwards, and then strengthening the construction with a thin clay sheet on the back. This technique provided a new freedom of expression. Figure 5 shows the boards with the inserted pieces cut into smaller pieces combined in oblique structures, thus obtaining more dynamic and flowing intarsia elements.

The fracture series exposes the outer limits of the porcelain material. Outside these limits, the material cracks. While these limits are far wider for casted tiles, the desired expressivity of hand-building is lost, and, presumably, so too is the deep, black colour. Adding grog to the clay would make a better material for hand-building. The clay would be less brittle. However, the desired expressivity of porcelain would then be affected. Moreover, cellulose, in the form of paper or flax fibres, could be added to reinforce the clay, but the material's expressivity would be strongly affected. Finally, there is also no doubt that size matters. The bigger the boards, the more tension and fracturing. Sticking to the $30 \times 30$ $\mathrm{cm}$ boards would be a much easier task. However, the very size of the smaller boards tends to make associations to bathroom tiles, which is far from my intention. Hence, in spite of the available remedies for the fracturing problem, artistic expression was prioritised throughout in the Porcelaneous Project.

In this problem-solving phase of the project, one might characterise the not-yet-known techniques of artisanship and epistemic things. Over time, the knowledge gained through these experiments became tacit, embodied and experiential. Given this starting point, the step-by-step craft improvement techniques became prerequisites for further experiments. The developing craft knowledge of hand-building porcelain gradually became a part of the technical objects of the project. The experiments needed for this development were small and modest, and the problems to be solved were not very complex. Neither are my small projects linked to larger research networks for the handling of complexity. Hence, these problem-solving experiments may not fit into Rheinberger's theories. Still, he underscored that small experimental systems, that is, small entities of experimental practice, are the pivotal elements in knowledge generation. As the field of artistic research grows larger and stronger, such minor experiments may find their place as components in more complex research networks. 


\section{The unforeseen}

The findings in the fracture problem-solving series made it possible to make full-scale hand-built boards. The hand-building technique and the touch of a human hand in the painting on the boards are pivotal to the artistic expression. The stern geometrical composition combined with the irregularities of the hand-building made a dynamic contrast. The layers of white fog were added as a translucent component in contrast to the rather bastant white and black clay bodies. In a series of experiments, the black square of the board and the white square of the inlaid clay were constants, while the white translucent layers of the painted slip were the variables (Figure 6).

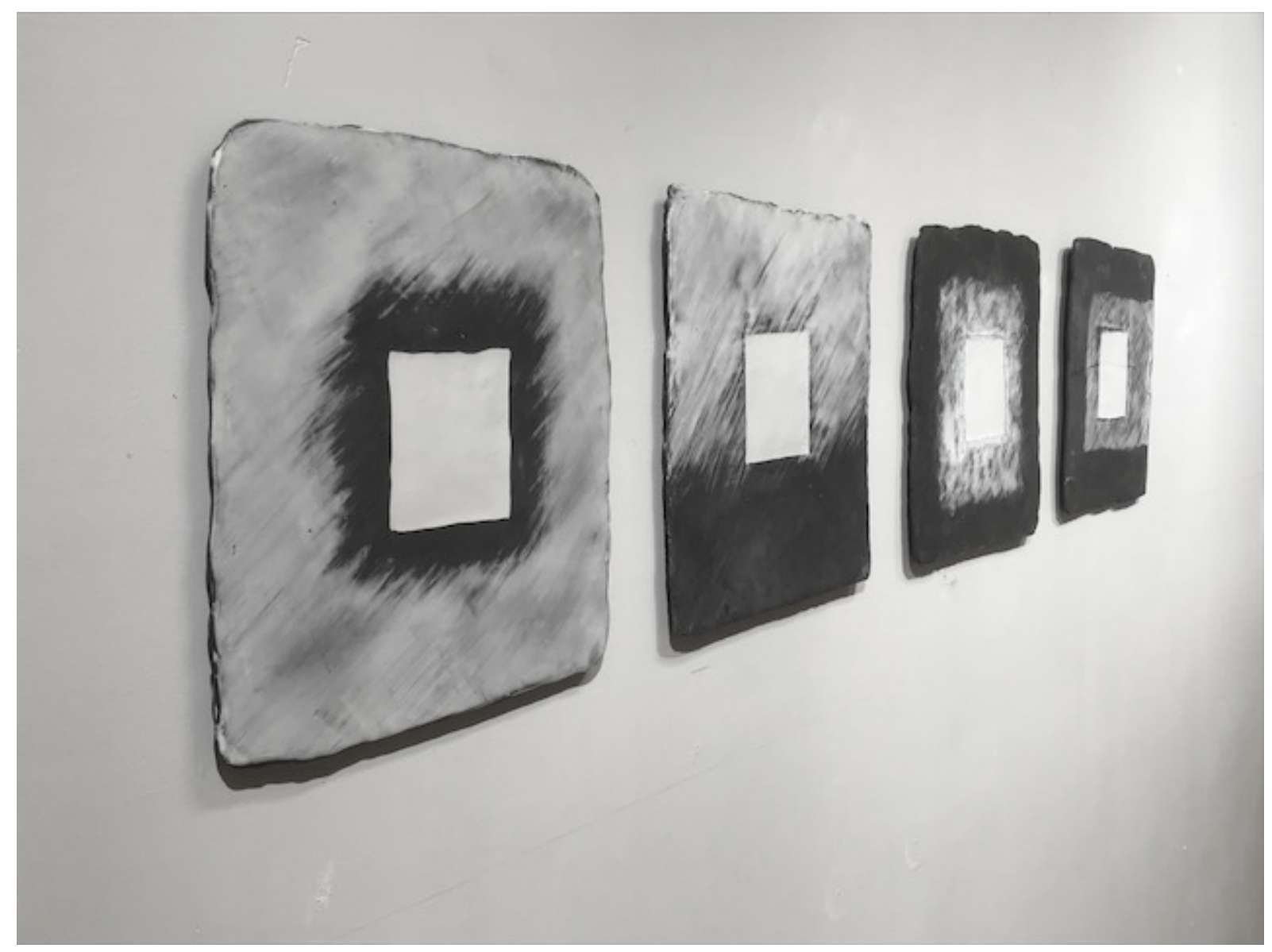

FIGURE 6. Four boards in an experiment series. Hazy Square. April 2019

At a certain point in this series of experiments, I mounted four boards in a gallery in order to take photographs. Seeing the series exposed on the gallery walls, I realised that the four boards united into one single artwork, encompassing a narrative of changing translucent shapes over constant forms. In this way, the experimental procedure became embodied-and exposed-in the final artwork. This was not planned. It was an unforeseen event, which, in turn, drew my intention towards larger, monumental artworks for exhibitions and public areas This unforeseen event changed the direction of the project. This did not just happen. It was facilitated by the problem-solving efforts. Given that experiments are open-ended, however small and humble, sometimes unforeseen things happen, which can actually redirect the entire project.

The artistic expression of the boards was the main objective of the experiments throughout this project. There were always easier ways to make them, preventing flaws and failures, but I rejected mitigations that affected the expression I sought. However, the artistic expression was never quite clear. It was related to a feeling, an enigmatic attraction, that drew the project in a certain direction. I relate this to the not-yet-known character, what was previously mentioned as the incompleteness or 'non- 
identity' of artworks as epistemic things, making room for the un-thought and unexpected (Borgdorff, 2013b, pp. 218-219).

Unforeseen events also occurred in additional experiments. I was looking for new ways to make clay slabs for intarsia, and I tried kneading blocks out of black and white clay. The lumps were then cut into slices of the appropriate thickness, and a black clay plate was built around them. An abundant amount of black slip was used as glue, and all precautions were taken for the new boards to succeed. In the end, the pattern was revealed with the help of a steel tool.
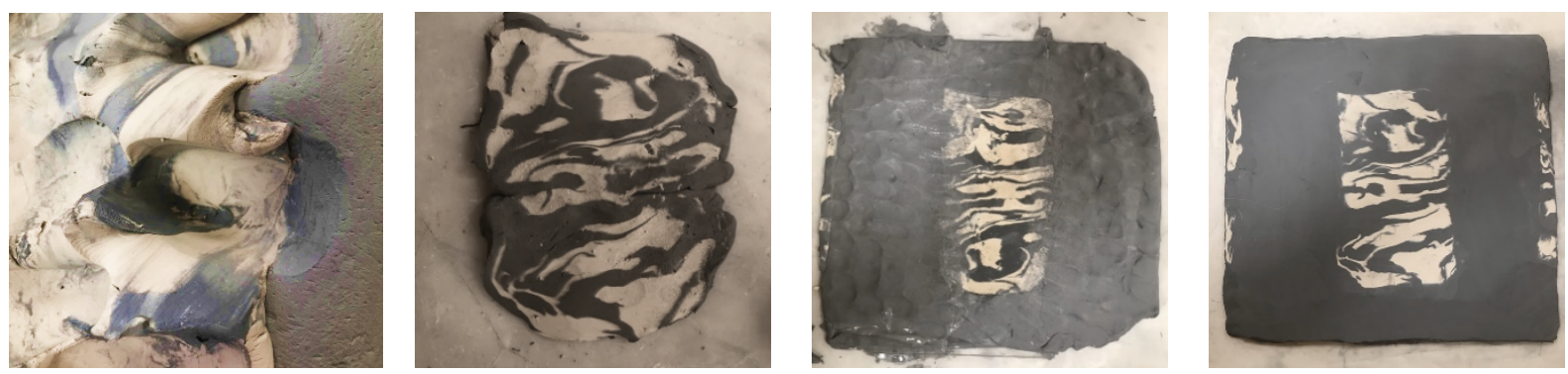

FIGURE 7. Kneading, slicing and inserting two-coloured clay shapes. February 2020.

The process entailed kneading together white and black porcelain, making cross-sections of the kneaded clay lump, building a black frame around the black-and-white slab, revealing the pattern and cleaning up the surface with a steel tool (Figure 7).

It occurred to me that the initial step, the kneading process, made an interesting expression. The plasticity of the material was clearly exposed; the traces of hands were obvious. With this rich plasticity, why should all the boards be flat? Why should they not go towards three-dimensionality? I realised that this was to be the starting point of a new line of investigation, a new series of experiments. Then, another thought emerged. The third image in Figure 7, the unfinished board, had explicit traces of a hand in a thin layer of black clay partly covering the inserted pattern. Why not leave these marks without smoothing the traces of hands? Why not let the black-and-white pattern emerge through this layer of handwork? This became the start of a second line of investigation, a new series of experiments. Hence, two lines of investigation occurred from this experiment: one line based on a structured, kneaded surface with black and white clay, another line based on the particular expression and design of inserted kneaded and sliced clay.
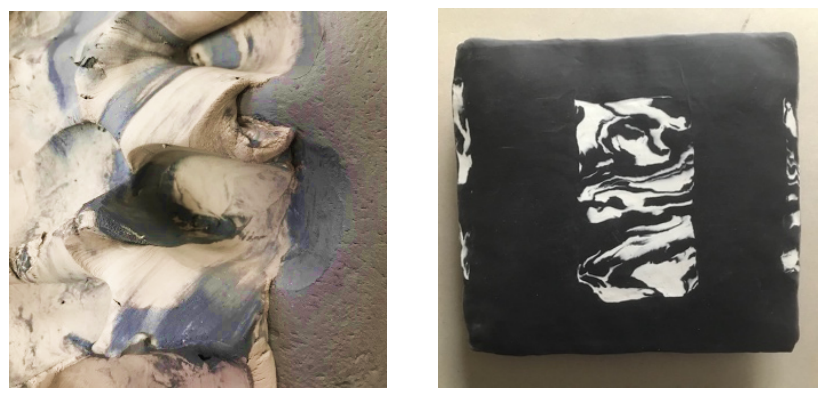

FIGURE 8. The starting points of two new series of experiments. Left: Three-dimensional structures. Right: Kneaded clay intarsia. February 2020

These are the kinds of bifurcations, or off-springs, that Rheinberger describes (Figure 8). In a larger setting, the off-spring lines of experiments might also cross and even merge. As I see it, bifurcations, crossings and merging lines constitute networks of experiments. These are not the larger networks in Rheinberger's model, since they are all created in one minor experimental entity. However, they show a similar dynamic within this small entity. 


\section{The Small-scale experiments}

The experiments discussed in this article may be too small to serve as examples for the theories of experimental systems and epistemic things. However, in a dialog with Schwab (2013), Rheinberger referred to Cézanne, who painted hundreds of apples in his series of still life paintings, repeatedly, with small changes and iterations.

I am interested in the creation of differences through such processes of iterations, be it in the sciences or in the arts. Holding these small differences against each other produce knowledge effects. The very process of iteration brings these slightly different variants of an experimental process into contact with each other. It is not the relation between a thinking mind and objects on the table in front of it, the classical relation between a subject and an object posed before it; the basic idea is to introduce multiplicity at the object-level itself and thus to get rid of the classical dualistic structure of epistemology [emphasis added] (Rheinberger in Schwab, 2013b, p. 215).

Hence, even small steps and minor iterations may fit this theory. Cézanne's experimental approach is not within the ground-breaking and border-transgressing tradition of 'experimental art'. They are meticulously conducted iterations aiming at the freedom of expression that depends on controlling the craft of painting.

The Porcelaneous Project is in its infancy; in this phase of a project, trivial problems must be solved. Remembering the warnings of Dyrssen (2011), there is a risk of searching for knowledge that already exists in the practice field, since craft techniques tend to reside in artists' studios as embodied, tacit knowledge. Hence, one benefit of artistic research should be the general obligation to share and disseminate the research outputs, as well as the transparency of the methods and procedures, allowing small studio experiments to contribute to larger patchworks of research.

\section{EPISTEMIC THINGS AND ARTISTIC RESEARCH EPISTEMOLOGY}

Epistemic things are the things that are not-yet-known, what one is searching for in an experimental project. Thus, epistemic things are vague and ambiguous, undetermined and indistinct. Knorr Cetina (2001) ascribed to epistemic objects the ability to infinitely unfold, which in Borgdorff's (2013) terms would be a fundamental incompleteness, like Adorno's non-identity, pointing towards an unfolding ontology. As I see it, research questions, so essential to academic graduate and postgraduate projects, can be regarded as attempts to capture epistemic things. As articulations of what we do not yet know, they are hard to formulate. The expectations of a research project may dwell in enigmas. As the project evolves, the epistemic thing should arise from its enigmatic state.

To me, the most triggering aspect is the concept of epistemic things as hybrids between objects and thinking; they are material objects, yet they have thinking embodied in them. In Rheinberger's terms, epistemic things are invested with meaning. In a dispute on whether to use the notion embodied in relation to this issue, Rheinberger (2005) explained:

If I say the concept of "gene" is applied to a virus, I remain in the world of naming. If I say it is embodied in a virus, I position myself in the world of experimentation, where I handle things like viruses according to what they are assumed to embody. [emphasis added] (p. 408)

In this respect, I associate epistemic things to the artistic object trouvée, a thing taken out of context and invested with meaning, like an epistemic object trouvée.

In the present debate on an epistemological platform, Rheinberger's concepts have aroused the interest of art researchers. Rheinberger suggested the material approach as a reason for this, as an acknowledgement of the material practice of artistic research. To this, I would add the use of experiments as a working method, the objective and laboratory/studio approach, the acceptance of small, locally manageable projects and the organisation of experiments to allow the unforeseen to happen. According to Kubler (1962), science and art both deal with needs that are solved by the mind and the hands in the manufacture of things. 
Schwab (2015) suggested that the theory of experimental systems and epistemic things could be a possible route to a genuine artistic research epistemology. Experimental systems, which are highly conceptual in nature, are meant to produce epistemic things that enter the world as unknowns. He suggested an artistic epistemology that focuses on the radical individuality of epistemic things, and the need for artistic research practice to protect its individuality as a site for particular knowledges. According to Schwab, he seeks to propose a post-conceptual understanding of experimental systems as the foundation for an artistic epistemology (Schwab, 2015).

From the experiences in the Porcelaneous Project so far, I have found that the theory of experimental systems and epistemic things is fruitful for reflections on the artistic research approach. I agree with Schwab's recommendation of a post-conceptual understanding of experimental systems, though not necessarily as the very foundation of an artistic epistemology. In particular, I find the terminology, the words, a fortunate contribution to the field of artistic research. I do not need concepts, such as 'epistemic things', for trivial problem-solving. However, for the search for material expressivity, the vague and enigmatic sensation of a particular artistic quality, the 'epistemic thing' seems to express just what it is all about. The introduction of the not-yet-known, the incompleteness or 'non-identity' of artworks as epistemic things seems to cover their enigmatic character, or the enigmatic attraction of the artistic expression that I search for. I also find the understanding of material things that have thinking embodied in them, invested with meaning, to reflect features of artistic research that are difficult to verbalise.

For doctoral projects residing in the zone of debate on whether artworks can or cannot be the result of research, the concepts of experimental systems and epistemic things as discussed in this article tend to be fruitful. From what I have experienced, they seem to be relevant both in the fields of life sciences and the arts, as discussed in this article. While I do not clam that these are similar disciplines, I still find that a discussion at a conceptual, epistemic level may contribute to the future acceptance of artworks as an integrated part of the research result. From this perspective, the enigmatic character of epistemic things may be investigated in further projects. 


\section{REFERENCES}

Biggs, M., \& Büchler, D. (2011). Communities, values, conventions, and actions. In M. Biggs \& H. Karlsson (Eds.), The Routledge companion to research in the arts (pp. 82-98). Routledge.

Borgdorff, H. (2011). The production of knowledge in artistic research. In M. Biggs \& H. Karlsson (Eds.), The Routledge companion to research in the arts (pp. 44-63). Routledge.

Borgdorff, H. (2013b). Artistic practices and epistemic things. In M. Schwab (Ed.), Experimental systems future knowledge in artistc research. Leuven University Press.

Callister, W. D., \& Rethwisch, D. G. (2015). Materials science and engineering (9th ed., SI version ed.). Wiley.

Dyrssen, C. (2011). Navigating in heterogeneity: Architectural thinking and art based research. In B. Michael \& H. Karlsson (Eds.), The Routledge companion to research in the arts (pp. 223-239). Routledge.

ECWC. (2005). European Ceramic Work Centre. The ceramic process. A manual and source of inspiration for ceramic art and design. University of Pennsylvania Press.

Groth, J. (2015) Ikon: Jan Groth/Interviewer: M. C. Lie. Ikon, NRK, Oslo.

Hannula, M., Souranta, J., \& Vadén, T. (2014). Artistic research methodology. Narrative, power and the public: Peter Lang Publishing.

Knorr Cetina, K. (2001). Objectual practice. In T. R. Schatzki, K. Knorr Cetina \& E. Von Savigny (Eds.). Routledge.

Kubler, G. (1962). The shape of time. Remarks on the history of things Yale University Press.

Lucas, P. (2013). The photographic absolute: An architectural beginning. (Doctoral thesis), Oslo School of Architecture and Design, Oslo.

Rheinberger, H.-J. (1997a). Toward a history of epistemic things: Synthesizing proteins in the test tube. Stanford University Press.

Rheinberger, H.-J. (1997b). Experimental complexity in biology: Some epistemological and historical remarks. The University of Chicago Press on behalf of the Philosophy of Science Association. Proceedings of the 1996 Biennia IMeetings of the Philosophy of Science Association. Part II: Symposia Papers (Dec., 1997), 64, 245-254. http://ezproxy1.usn.no:2154/stable/188407.

Rheinberger, H.-J. (2005). A reply to David Bloor: "Toward a sociology of epistemic things". Perspectives of Science, MIT, 13(3), 406-410.

Rouse, J. (2001). Two concepts of practices. In T. R. Schatzki, K. Knorr Cetina, \& E. Von Savigny (Eds.), The practice turn in contemporary theory. Routledge.

Schwab, M. (2013a). Experimental systems: Future knowledge in artistic research. Leuven University Press.

Schwab, M. (2013b). Forming and being Informed. In M. Schwab (Ed.), Experimental systems future knowledge in artistic research. Leuven University Press.

Schwab, M. (2015). Experiment! Towards an artistic epistemology. Journal of Visual Art Practice, 14(2), $120-131$. http://doi:10.1080/14702029.2015.1041719

Solberg, A. (2017). Developing doctorateness in art, design and architecture. (PhD, University College of Southeast Norway, Notodden). (15) http://hdl.handle.net/11250/2442970

Stallschus, S. (2013). A theory of experimentation in art? Reading Kubler's history of art after Rheinbergers's experimental systems. In M. Schwab (Ed.), Experimental systems future knowledge in artistic research (pp. 15-25). Leuven University Press. 